\title{
Understanding Livelihood Diversification Patterns among Smallholder Farm Households in Southern Ethiopia
}

\author{
Tagesse A. Melketo ${ }^{1}$, Endrias Geta ${ }^{2} \&$ Stefan Sieber ${ }^{3,4}$ \\ ${ }^{1}$ Institute of Development \& Policy Research (IDPR), Wolaita Sodo University, Ethiopia \\ ${ }^{2}$ Southern Agricultural Research Institute, Ethiopia \\ ${ }^{3}$ Department of Agricultural Economics, Humboldt University of Berlin, Unter den Linden 6, 10099 Berlin, \\ Germany \\ ${ }^{4}$ SusLAND: Sustainable Land Use in Developing Countries, Leibniz Centre for Agricultural Landscape \\ Research (ZALF e. V), Eberswalder Str. 84, 15374 Müncheberg, Germany \\ Correspondence: Tagesse A. Melketo, Institute of Development \& Policy Research (IDPR), Wolaita Sodo \\ University, Ethiopia. Tel: 251-912-033-352.E-mail: tagesse.melketo@wsu.edu.et
}

Received: October 16, 2019 Accepted: November 20, 2019 Online Published: November 29, 2019

doi:10.5539/sar.v9n1p26 URL: https://doi.org/10.5539/sar.v9n1p26

\begin{abstract}
Smallholder farm households face an increasing need of looking for alternative income sources to supplement their small scale on-farm incomes. However, livelihood diversification is a complex phenomenon and it involves different forms. This study, therefore, delves to realize the patterns of livelihood diversification strategies adopted by the smallholder farmers at Kembata-Tembaro zone, Southern Ethiopia. The study was based on cross-sectional survey data from 384 farm households that were selected through a combination of three-stages: cluster, simple random, and proportional to the size of population sampling techniques. A mix of instruments including interview- schedule, focus group discussions, key informant interviews and field observations were used to acquire primary data. Descriptive statistics in combination with multidimensional approaches involving cluster analysis were used to analyze the quantitative data. The qualitative data were analyzed using word descriptions and verbatim discussions. It was found that the diversification patterns of the smallholder farm households in the study area took different forms involving alteration of land use patterns, intensification of crops and livestock productions, and non/off-farm activities. Superiority order of livelihood strategies in terms of the average annual cash income obtained by the households was set. Accordingly, commercial crop stands first followed by livestock rearing and subsistence crop production as second and third, respectively. It was suggested that livelihood diversification can only be a viable strategy to achieve sustainable rural livelihoods if the farmers are capacitated so that they can choose the right remunerative livelihood strategy among the existing options.
\end{abstract}

Keywords: livelihood strategies, diversification, cluster analysis, smallholder, Ethiopia

\section{Introduction}

Agriculture is the mainstay of Ethiopian economy, accounting for $83.9 \%$ of exports, and $80 \%$ of total employment (FAO, 2011). It constitutes over 50\% of the gross domestic product (GDP), accounts for over $85 \%$ of the labour force and earns over $90 \%$ of the foreign exchange (Alemu, Oosthuizen \& Schalkwyk, 2010). On average, crop production makes up $60 \%$ of the sector's outputs, whereas livestock accounts for $27 \%$ and other areas contribute $13 \%$ of the total agricultural value added. The sector is dominated by small-scale farmers who practice rain-fed mixed farming by employing traditional technology, adopting a low-input and low-output production system. The land tilled by the Ethiopian small-scale farmer accounts for 95\% of the total area under agricultural use, and these farmers are responsible for more than $90 \%$ of the total agricultural output (Gebreselassie \& Bekele, 2010).

Despite its proven advantages, the small farms led development paradigm is widely challenged today and there is considerable debate about its continuing relevance for Ethiopia as well. Critics continue amplifying the limitations of small-scale farming for economic growth, poverty reduction, food security and creation of employment (Dercon \& Collier, 2013; Dercon \& Zeitlin, 2009; Fan et al., 2013; Hazell, 2013). Smallholder farming as a primary source of income has failed to guarantee sufficient livelihood for most farming households 
in Ethiopia (Ellis, 2001; Babatunde, 2013). The sector is highly characterized by decreasing farm sizes, low levels of output, and a high degree of subsistence farming (Smith et al., 2001). Ever increasing rural population on a fixed (even fragmented and shrinking) farm land basis puts small-scale farmers under pressure. Less access and competence to high value markets due to the challenges of high standard requirements, and low level of productivity due to the limited access and low level of utilization of improved and economically viable farm technologies (Ellis \& Freeman, 2004) has put the system trapped in a vicious circle of poverty.

Handful of empirical studies (Block \& Webb, 2001; Degefa, 2005; Woldehanna \& Oskam, 2001; Barrett et al., 2001; Zerai \& Gebreegziabher, 2011; Ali \& Reta, 2012; Amare \& Belayneh, 2013) in Ethiopia suggest the necessity of diversifying rural livelihood activities underlining the fact that the smallholder agriculture provides only limited portion of household income. The common point of their argument is that in most rural situations of Ethiopia, the land scarcity by the farmers coupled with agricultural risks could not generate enough household income had it not been for other sources of income there apart from the agricultural production. The objective for this study, therefore, is of two-fold. First, understanding the dynamics of rural livelihood strategies within household is a key for rural development and poverty alleviation plans. Second, the question of level of lucrativeness of the livelihood strategies employed by households in the context of smallholder farms yet remains unanswered in the study area.

\section{Conceptual Framework of the Study}

Among the two approaches commonly used in the economic literature to study livelihood diversification behavior: 'the household economic model' (Singh, Squire \& Strauss, 1986; Taylor \& Adelman, 2003) and 'the livelihood approach' (Ashley \& Carney, 1999; Chambers \& Conway, 1992; Scoones, 2009), the later has been widely used in empirical studies of livelihood strategies and adaptation. The approach has its strength in recognizing the multiple and diverse character of livelihoods (Ellis, 1998, 2000a; Ellis \& Biggs, 2001) and has proved useful in examining the diversity of farming systems (Sourisseau et al., 2012). It also employs the 'sustainable livelihoods framework' to assess people's livelihood diversification. Thus, the present study prefers the livelihood approach.

Clustering households in terms of their livelihood diversification strategies is the other concern which needs determination of appropriate analytical approach. Household categorization is not only necessary to target existing livelihood groups, but also for designing effective and targeted poverty-reducing strategies. The vast majority of previous studies dealing with livelihood diversification have used household total income as a main criterion (Cavendish, 2000; Rui, Jianing, Shu \& Xia, 2019). In most of the previous studies, categorization of household in to livelihood strategy groups have been done either according to the income shares from different sources, or according to the main income activity as stated by the household while responding to survey instruments. Both options have some limitations. Firstly, households tend not to disclose their income for various reasons. In fact, the classification on the basis of the income shares requires income to be measured properly, but which is very difficult (Laura et al., 2012) for some activities such as farming, a dominant livelihood strategy in smallholder context of developing countries. Secondly, income is susceptible to fluctuations for various reasons. Suppose that a farming household has lost its production and has zero or negative income may be due to climate change. But its livelihood is still agriculture even if the income is non-positive. Therefore, it has a tendency to misrepresent households' livelihood classes. Alternatively, the classification based upon the stated main income generating activity is problematic because it imposes a household with different sources of income to select the main source from a pre-determined arbitrary list.

This study, however, is different in that it adopts a different approach. Each household is classified according to its own livelihood strategies as resulting from cluster analysis. The rationale behind is that the concept livelihood strategy is not only about income share or income generating activities, rather it involves various capitals (human, social, physical, financial, natural and political) that make the household welfare (Ellis \& Biggs, 2001). So, livelihood strategies analysis and classifying households on the basis of their livelihood strategy groups needs a multivariate technique that encompasses algorithms and methods for grouping different observations into categories with common livelihood patterns. Thus, using information on shares of income sources, productive assets, and occupational activities of households, it has been used to allow the data to identify the most meaningful and homogenous groupings of farm households in southern Ethiopia.

\section{Research Methodology}

\subsection{Description of the Study Area}

The study was conducted in Kembata Tembaro zone of southern Ethiopia. The administrative zone is located in the south west about 350 kilometers away from the national capital, Addis Ababa. It bordered in the north by 
Hadiya administrative zone and the Alaba Special woreda; in the south by Walayta zone; in the east by the Billate River which separates it from the Arisi zone of Oromiya Regional State (Abo, Rajan \& Geta, 2018).

Kembata Tambaro zone comprises seven woredas, namely Kadida-Gamela, Damboya, Angecha, Doyo-Gena, Kacha-Bira, Hadero-Tunto and Tembaro, and two town administrations with a total area of $1,356 \mathrm{sq} . \mathrm{km}^{\mathrm{i}}$. The zone is one of the most densely populated areas in the country with average population density of 588.5 people per sq. km (Central Statistics Agency (CSA), 2012). Astronomically, the zone lies between $7^{\circ} .10^{\prime \prime}$ to $7^{\circ} .50^{\prime \prime}$ latitudes and $37^{\circ} .34$ " to $38^{\circ} .07^{\prime}$ 'longitudes. Concerning the land feature of the zone, of the total land, $75.23 \%$ is cultivated land; $6.19 \%$ is grazing land, $6.73 \%$ is covered by bush and forest; $3.41 \%$ is arable, but unutilized; $3.11 \%$ uncultivable land, and the remaining $5.31 \%$ is covered by others (Southern Nations, Nationalities and People's Region (SNNPR), 2008).

The administrative zone has three agrological (traditional) zones, comprising $13.7 \%$ wet (dega), and $71.17 \%$ mid-temperate (weyna-dega) and $11.14 \%$ is hot (kolla). The annual average temperature of the zone ranges from 126 to $27.5^{\circ}$ Celsius and the annual average rainfall ranges from 1001 to $1400 \mathrm{~mm}$ (SNNPR, 2008). Topographically, it lies between elevations ranging from 501 to 3000 meters above sea level.

The economy of the zone is predominantly agriculture-based, which is the major source of employment and livelihood. The zone is suitable for crops such as enset, root crops, maize, wheat, fruits and vegetables. Around $90 \%$ of the zone population depends on agriculture, with crop production constituting the basic economic activity and main source of livelihood for the rural population, followed by livestock rearing. According to Girma (2013) and Mulgeta (2014), Kembata Tembaro zone is a better representative to the general biophysical and socio-economic features that characterize the livelihood attributes of the "enset-belt" areas of southern Ethiopia. The following figure describes the map of the study area. Enset (Enseteventricosum) is the source of waasaa, the staple food of people in southwest Ethiopia (Kembata, Temabro, Hadiya, Wolaita, Sidama, Gedio and Guragie). Indigenous to East Africa, and widely distributed in sub-Saharan Africa, enset is hardly known as a food plant outside of Ethiopia where it is an important, drought-resistant crop that feeds millions of people, mostly those living in SNNPRS (Brandt et al. 1997).

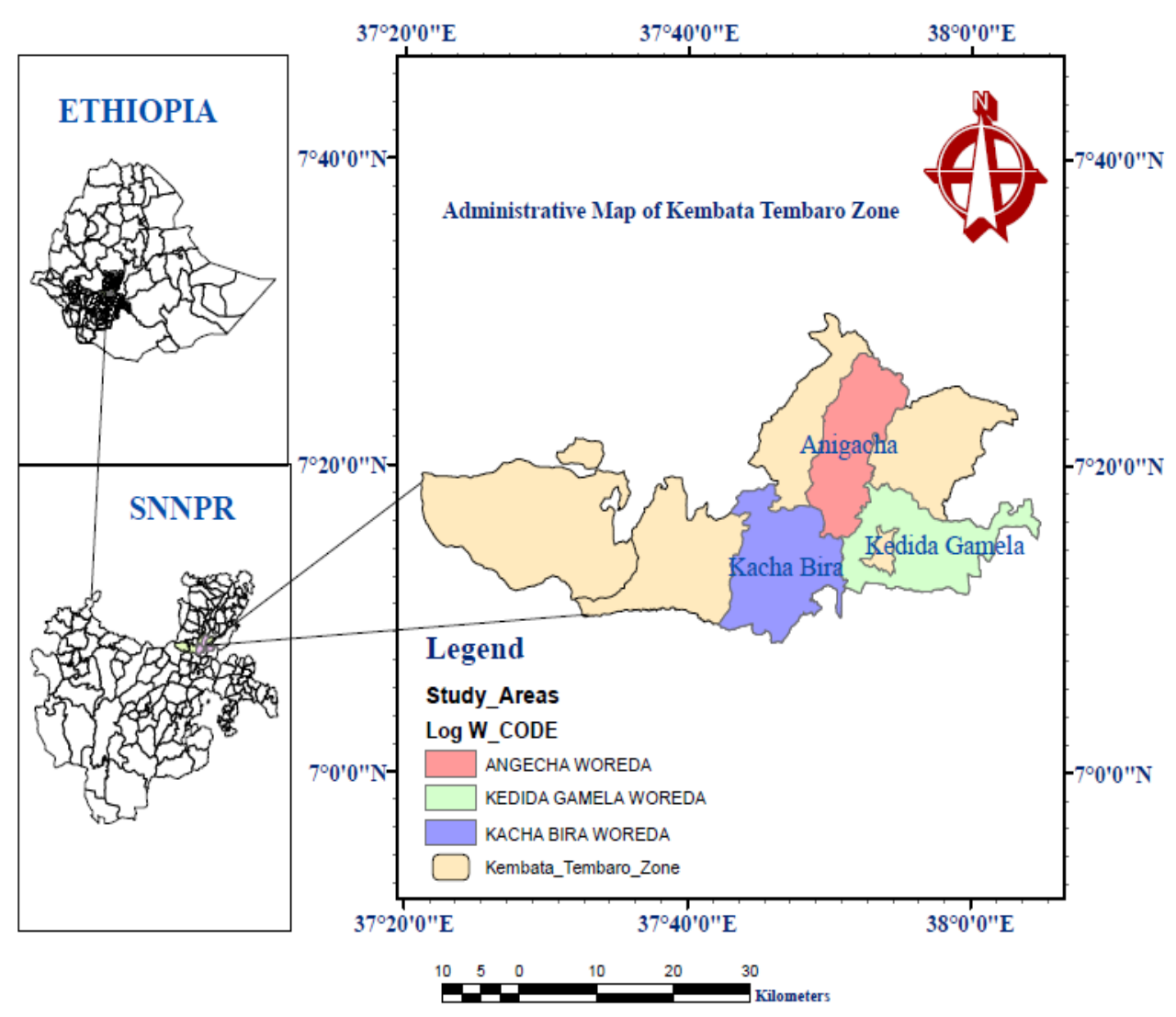

Figure 1. Map of the Study Area

Source: GPS Map: June, 2019 


\subsection{Sample Size Determination}

Since this study was mainly quantitative in its design, one of the appropriate criteria to determine the representative sample size- degree of variability in the attributes (livelihood strategies' diversification, in our case) being measured (or prevalence) was used. The proportion of 50\% (the maximum variability in terms of diversifying livelihood strategies) was assumed helpful in determining the more conservative sample size. Accordingly, among the several mathematical sampling formulas, the one presented by Cochran (1963) (Equation 1) was employed to determine the study sample size.

$$
n_{0=\frac{Z^{2} P Q}{e^{2}}}
$$

Where, $n_{0}$ is the sample size, $Z^{2}$ is the abscissa of the normal curve that cuts off an area $\alpha$ at the tails, (1- $\left.\alpha\right)$ equals the desired confidence level (95\%, in our case), $e$ is the desired level of precision, $p$ is the estimated proportion of an attribute that is present in the population, and $q$ is 1-p. The value for $Z$ is found in the statistical tables which contain the area in the normal curve $(Z=1.96$, in our case).

\subsection{Sampling Procedures}

Multistage sampling technique was used to select the research districts and the sample respondents. First, three districts (or woredas) were selected using cluster sampling method. Out of the 7 woredas comprising the administrative zone, three woredas, namely Kedida-Gamela, Kacha-Bira and Angecha were selected to capture different livelihood clusters. According to the zonal Agricultural Office records, following the cropping attributes the zone is classified into three: cereal and enset livelihood cluster, the ginger cluster, and the coffee livelihood clusters. On this basis, the three woredas (one from each cluster) were included in the study as they represent the three clusters, respectively.

Second, out of the districts, six kebeles were selected using stratified random sampling technique. The kebeles in each woreda were listed based on their agro-ecological characteristics and stratified into three ecological zones namely, highland (dega), midland (woine dega) and low land (qola). Based on this, 2 kebeles from each agro-ecology (totaling 6) were included in the study. A total of 384 farm households were then selected using random sampling technique from the list of households by respective Peasant Associations (PAs) in each of the selected kebeles. The sample size from each kebele was then made proportional to the sample size (i.e. number of households in the kebele).

\subsection{Instruments and the Data}

Cross-sectional field survey was carried out using a mix of various instruments including interview- schedule and participatory rural appraisal (PRA) methods to acquire the necessary primary data. The first step in the data collection was PRA which involve identifying common livelihood diversification strategies, household asset basis and income sources. This exercise using focus group discussions (2 FGDs per kebele) resulted in identification of community specific livelihood strategies, basic rural household asset endowments and pillar income sources, while the key informant face-to-face interviews with people who know well what is going on in the community ( 2 per kebele totaling 12-including community leaders, woreda level professionals, and extension workers)enabled to get in-depth information which helped to triangulate the data through other tools. Each focus group consists of six participants. The discussion in each FGD took about an hour. This had, in fact, been done before the designing of questions for household survey.

Following the PRA exercise, a detailed survey schedule was prepared to collect quantitative data on the indicators already identified in the qualitative methods and other background characteristics of households. Trained enumerators administered the survey and field work was supervised on a day-to-day basis by the researcher to ensure enumerators' compliance with established survey procedures. The field survey took place within three months ranging from April to July, 2016.

\subsection{Analytical Procedures}

\subsubsection{Income Generating Activities and Income Accounting}

To determine the number of major income sources that households in the study area use for their livelihood and to calculate the annual income that each household obtained from the given number of major sources, four simplifying assumptions were made. Following the lead of approaches by previous studies that focus on 'household income' (Cavendish, 2002; Twine et al., 2003; Fisher, 2004; Naraian et al., 2005) conjugating it with the local knowledge obtained through the PRA exercises with the community representatives, six major income sources (livestock rearing, subsistence crop production, commercial crops production, wage employments, rural 
enterprises and occupational migration) were identified and accounted for:

(a) Smallholder farmers may be pulled by commercial gains obtained and willing to diversify away from food crop production into higher value cash crops and/or other profitable activities (Key et al., 2000). As a result, tendencies toward commercialization and self-employment practices on rural emerging enterprises are alternative livelihood strategies.

(b) The time-varying nature of agricultural work enables smallholders to search for complementary employment. Occupational in and out migrations, therefore, are common livelihood diversifying strategies among resource scarce, smallholder farmers.

(c) The rural poor households are facing paradox in that while they would most need income diversification, they are less able to become engaged in higher remunerated off-farm activities due to entry barriers and difficulty in startup finances (Woldehanna \& Oskam 2001; Zerai \& Gebreegziabher, 2011). Consequently, much of the income diversification in smallholder context is characterized as casual and limited to unskilled wage labour (Barrett et al., 2001).

(d) Own-labour value was not deducted from net income. For poorrural households working in areas where labour markets are absent or thin and alternative opportunities are limited, imputing the opportunity cost of labour time (shadow wage rate) is difficult. Therefore, the net income is inclusive of own-labour costs.

Following these assumptions, each of the six income items was estimated as follows:

(1) Net crop (subsistence) income: In calculating net crop income, gross crop income was derived by measuring the value of different end-period products of food crops (enset, pulses, cereals, root crops) over the year for each household using March-May, 2016 local market prices. Next, the values of crop inputs (fertilizers; ploughing services; seeds and any payment to hired labour) were summed to obtain a measure of total crop input costs. Then, these values were deducted from the values of gross crop income to obtain the net crop income.

(2) Commercial crops' income: Income from commercial crops (ginger, coffee, $k$ chatt, potatoes and banana) is defined as a total income from sales of these crops minus values of crop inputs.

(3) Livestock rearing income: Livestock income consists of three main sub-components: livestock sales, livestock products, and services. To value the first two sub-components local market prices were used. Imputed values were used for livestock services in the form of ploughing and transport services, for example. Summing the three sub-components yielded gross livestock income. Next, annual expenditures on cost items such as purchased fodder or straw, veterinary services, and hired labour were aggregated to obtain the total costs of livestock production. Deducting total annual cost from gross livestock income resulted in net income from livestock.

(4) Income from rural enterprises: Income from household enterprise is defined as income from any non-agricultural enterprise operated by a household member. Such activities may comprise petty trade, small-scale market productions like crafts, food and drinks processing, services, and other cash generating business activities such as renting. Rural enterprise income is defined in net terms, that is, net of any costs incurred related to a person's engagement in an activity.

(5) Income from wage employment: The PRA exercises enabled to distinguish three categories of wage employment, namely (i) in-village casual employment off the household's own farm, (ii) off-village casual employment, and (iii) regular employment in the private or public sector. Income from wage employment is defined as the sum of cash and in-kind wages received from these three categories of employment. Many households in the study area participate in food-for-work (FFW) activities in which they receive food in return for their labour services. Such activities include public works such as road construction or maintenance, soil and water conservation activities, and forest rehabilitation.

(6) Net remittances (gifts): It is common practice that rural households in Ethiopia receive transfers in kind or cash from family members, relatives, and sometimes government agencies or NGOs. We added up all the remittances, gifts or transfers received during the year by the household and subtracted the amount remitted out, if any. A number of rural households in the study area have at least an individual out migrated from the family to either Republic of South Africa or Arab Nations for searching better job opportunities.

\subsubsection{Clustering Sample Households}

In empirical literature, a series of rules have been used to classify a sample into pre-defined groups pursuing similar livelihood strategies (Freeman et al., 2004; Barrett et al., 2005; Ellis \& Bahiigwa, 2003; Ellis \& Mode, 2003; Ellis \& Allison, 2004; Ellis \& Freeman, 2005). These varieties of approaches in the existing works emerge 
from different theoretical foundations. But the common draw back with these approaches is that livelihood strategies are identified by broad but inherently arbitrary rules that partition the sample among exogenously defined groupings of activities, for example by looking at activity choices in different income quartiles (Barrett et al., 2005). This paper opts instead to let the data tell us how best to partition the sample into statistically distinct livelihood strategies reflecting how households allocate assets across the six different activities identified.

One of the approaches gaining popularity in the econometric literature (Winters et al., 2002; Petrovici \& Gorton, 2005; Brown et al., 2006; Jansen et al., 2006) is a cluster analysis, which is an iterative, data-driven approach. Most applications of cluster analysis consist of mathematical partitioning of the data in some form or another, where each observation, in this case household, belongs to a single group. In order to segment smallholder farming households, therefore, Cluster Analysis (CA) was chosen due to its strength in finding homogenous groups based on a wide range of variables.

It is often argued that there is no single method to determine the most suitable number of clusters and therefore both hierarchical and non-hierarchical methods are often used together to enable stability within the approach (Bidogeza et al. 2009). The former is used to create the dendogram from the hierarchical clustering method which fuses households together which are the closest to each other and can vary in terms of the specific agglomerative techniques used. The algorithm used in this analysis was Ward's (1963) method and the Euclidean distance measure. Besides, the non-hierarchical method was then used for clustering the data units into a single classification of cluster determined by a priori selection.

Lead by previous studies with farming typology cases (Ballas et al., 2003; Maseda et al., 2004; Gaspar et al., 2008; Alinovi et al., 2010; De Graaf, 2011), the most important factors which explain variation with the data were identified and used as the input variables for the livelihood strategies clustering. The information on share of income generating activities, land size, livestock ownership, and whether a household received transfers or not were used to allow the data identify the most meaningful and homogeneous livelihood strategy groups of households (Table 1).

Table 1. Explanatory variables used in the cluster analysis

\begin{tabular}{lll}
\hline Variable & Descriptions & Measurements \\
\hline LIVSINC & Share of livestock income & ETB \\
SUBCROP & Share of food crops income & ETB \\
COMCROP & Share of commercial crops income & ETB \\
WAGE & Share of casual employments income & ETB \\
ENTERPR & Share of micro-enterprises income & ETB \\
REMMIT & Share of net remittances or gifts received during the year 2016 & ETB \\
TLU & Livestock owned & TLU \\
TRANS & Whether a household head or a member received transfers in & Dummy \\
& cash or kind during the year 2016 & \\
LAND & Land ownership & ha \\
\hline
\end{tabular}

After identifying the variables associated with the livelihood strategy differences among farm households and measuring the accounts of each variable for a household, the cluster analysis was estimated according to the $\mathrm{K}$-mean values within clusters in order to understand differentiation amongst the farming household groups. The generic statistical model, according to Green (2012), for cluster analysis is expressed as follows:

$$
Z=\left[\begin{array}{ccc}
Z_{11} & Z_{12} & Z_{1 p} \\
Z_{21} & Z_{22} & Z_{2 p} \\
\vdots & \vdots & \vdots
\end{array}\right]
$$

Where, $Z$ is the different value of each explanatory variable, $Z_{i j}$ in $Z$ gives the z-score of the $i^{t h}$ variable on the $j^{\text {th }}$ household. The rows correspond to the variables of interest (in this case household accounts of each indicator variable) while the columns correspond to the different households in the data.

In order to understand the closeness between different households, proximity measures are used to identify dissimilarities, similarities and distance between elements in the data (Everitt et al., 2011). In clustering households in the data, the unit of proximity is usually expressed as a distance, and is dependent on the format of the specific data used in the clustering procedure. 


\section{Results and Discussion}

\subsection{Rural Livelihood Strategies' Diversification Patterns of Farm Households}

Livelihood strategy diversification in the context of rural farm households is a comprehensive phenomenon involving different patterns and portfolios of activities ranging from diversifying farm practices and endowments to looking for off/non-farm options. Within the community of the research area, diversification takes many forms. In this study, we focus upon two areas: first, diversification within agriculture which includes land use, crops, livestock diversification, intensification and extensification practices; and second, diversification in major income generating activities. Discussion of results on the diversification patterns is followed by classifying farm households systematically into livelihood clusters.

\subsubsection{Livelihood Diversification within Farm Activities}

Most of the existing studies considered about leaping out of the agriculture or off/non-farm diversification, and the issue of diversification within agriculture is yet given less attention by researchers as livelihood strategy of small holder farmers (Lioa et al., 2014b). Diversifying agricultural activities and alteration of agricultural resource endowments like land and household labour usually serve as ex ant risk reduction or ex post risk management strategy. The subsequent sub-topics describe the findings of this study regarding the livelihood diversification strategies employed within agriculture by smallholder farmers.

\subsubsection{Land Use Diversity}

Most of the farms surveyed (75\%) were with average land size of 0.38 ha and below; with a mode of 0.33 ha and with average of 0.26 ha and 0.31 ha cultivable land and total land owned, respectively (Table 2). Scarcity of agricultural resources, particularly farm land, is the other characteristic of describing the smallholder farmers. Results of this study endorsed this fact in that the mean farm land holding of the households was 0.31 ha. Adesiji et al. (2010) have reported an average land size of small-scale farmers in Nigeria is as low as 1 hectare.

The results indicate that most of the households maintain their livelihoods based on a very limited size of farm land. Farmers with limited cultivable land in the study districts often increase the area they use for cropping by annexing (hiring, renting, sharecropping) other pieces of land scattered around the villages. The total land size of a household is defined, here, as the sum of plots (cultivable land, rent in land, rent out land) deducted to land transferred, if any.

Table 2. Land distribution among the sample households $(\mathrm{N}=384)$

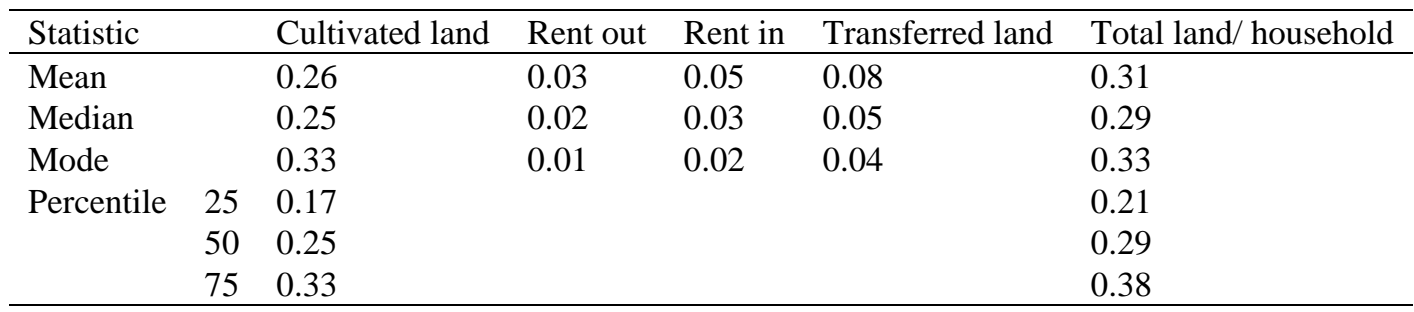

Source: Survey data (2016)

The land-holding size indicates that the agricultural land distribution among the sample farm households is highly coincident with the features of 'marginal farmers' described in previous literature (FAO, 2011; Bernard et al., 2007). These are agrarian for whom farming is a major livelihood activity, yet who have insufficient assets to produce a surplus from their on-farm activities. Land ownership in this study does not mean that rural households privately own the land, but rather that they have lifetime "holding or land tenure". According to the Ethiopian land law, all lands in Ethiopia are owned by the state, while individuals only have the right to use and/or transfer them. Land sales and mortgage are prohibited, but the right to use land can be transferred in the form of rent and bequest (Yigremew, 2002). The interval in the initial two categories were kept relatively smaller than the other categories in order not to obscure some important distinctions among smallest land holding farmers by a formidable collapsing for dimension reduction.

During the focus group discussions, it was pointed out that there are three types of lands owned by the households in the study area. That is, no matter how small the household land size is, almost all of the observed farmers have sub-fragmented their holdings in to three different plots. The first type is crop land, which is directly associated with the peasantry livelihoods. It is the cultivable land which is meant for cropping and seasonally rotated for various subsistence cereals, crops and roots which are sources of household food needs 
and commercial items. The second portion of plot is pasture land including both the summer and transitional pastures closer to overwintering villages. Summer pastures serve as the places for fattening livestock, while transitional pastures provide forage in spring. Such part of lands is very crucial for livestock production. Tree plantation fields are another important portion of land that is often identified for cultivation of various trees like eucalyptus tree which are means of income through sales of wood, timber and furniture, used for construction and fuel wood and charcoal. Trees are also planted as erosion and wind breaks in the compound/yard.

Studies which focus on nexus between farmland scarcity and livelihood diversification agree that, in instances where agricultural land scarcity is a serious predicament, intensification (the use of a greater amount of non-land resources (labor, inputs, etc.) for a given land area, so that a higher output is produced (Hussein \& Nelson, 1999)) and extensification (which takes different forms: it can mean putting more and more land into cultivation in most cases at the expense of natural resources like forests, range land and formerly unused areas; or it may to mean readjustment of land to the changing situation (Reta \& Ali, 2012) of farmland has been the other widespread alternative strategies used by rural people so as to adapt with the failure of the traditional livelihood strategies (Geremew, 2017).

Supplementing these findings, the data from the present researcher's observation during the transect walk, and respondents' reflections during the key informant interviews depict that there was high reallocation of land to the situations altering in the study area, though there is no ideal and burn type of farmland extensification. It was found that majority of land scarce farmers were pushed to cultivate fragile lands such as mountain sides, river edges, valley bottoms, and steep slope areas. In almost all of the kebeles, it was observed that areas which had been traditionally set as range land were put into cultivation and the forest areas are encroached. The high demand to meet family food needs pushes farm households to expand crop land, though it is done, as disclosed by the stakeholders during the FGDs, at the expense of environmental stabilities. The participants described the trend as "first the grazing land is put into cultivation and then the forest areas including the surrounding mountainsides are gently encroached." To cope with the farmland scarcity, the small holder farmers in the study area were practicing maladaptive agricultural extensification strategies.

In this study, intensification is manifested in various forms which involve mainly active working strategies, such as intensive ploughing and dynamic crop rotations. The high intensity of cropping and reducing vegetation cover were observed in the study districts. Due to ever increasing population pressure and subsequent land fragmentation, the practice of fallowing which is argued as extremely important to restore soil fertility in traditional agriculture (Eyasu, 2002) has almost become unlikely in the study area. About $98 \%$ of the household heads who were interviewed responded that they did not leave any of their cultivable plots un-cropped during any of the ten successive crop seasons past to the season immediate to the field survey time.

\subsubsection{Livestock Diversity}

Livestock diversification is an important livelihood strategy adopted by smallholder farmers to minimize exposure to risk. The livestock portfolio maintained by the sampled households mainly consists of cattle, sheep, and goats, as well as a number of horses and donkeys (Table 3). Rearing a mix of large cattle and small ruminants uses to play different roles for a family. Cattle and ruminants serve for cash earnings as the livestock or their products are sold. Livestock productions like beef, milk, butter, cheese, and hides are the major household income sources. They also satisfy household food demands. Horses and donkeys are kept for transportation. Oxen usually serve as traction animals where farm land is highly fragmented and agriculture is small-scale and not mechanized.

Table 3. Average number of livestock owned by the farmers in the study woredas

\begin{tabular}{lllllllll}
\hline \multirow{2}{*}{ Animals owned } & \multicolumn{2}{l}{ Angecha $(\mathrm{N}=119)$} & \multicolumn{2}{l}{ Qacha $(\mathrm{N}=148)$} & \multicolumn{2}{l}{ Qadida $(\mathrm{N}=117)$} & \multicolumn{2}{l}{ Total $(\mathrm{N}=384)$} \\
\cline { 2 - 9 } & Mean & SD & Mean & SD & Mean & SD & Mean & SD \\
\hline Cows & 0.79 & 0.627 & 0.88 & 0.513 & 1.09 & 0.921 & 0.93 & 0.738 \\
Oxen & 0.79 & 0.487 & 0.75 & 0.523 & 0.92 & 0.796 & 0.83 & 0.636 \\
Goats & 0.17 & 0.496 & 0.97 & 1.017 & 0.58 & 1.030 & 0.57 & 0.946 \\
Sheep & 0.87 & 1.283 & 0.69 & 0.771 & 0.59 & 1.189 & 0.71 & 1.114 \\
Donkeys & 0.46 & 0.534 & 0.27 & 0.467 & 0.26 & 0.454 & 0.32 & 0.491 \\
Mules & 0.03 & 0.159 & 0.01 & 0.093 & 0.03 & 0.163 & 0.02 & 0.144 \\
Horses & 0.12 & 0.397 & $\ldots$ & $\ldots$ & 0.01 & 0.116 & 0.04 & 0.237 \\
Chicken & 2.88 & 2.102 & 2.34 & 1.687 & 3.82 & 3.958 & 3.08 & 2.941 \\
\hline
\end{tabular}


Poultry production which is means of household livelihood and food security in the area is also worth to mention. Chicken and egg are common products mainly considered as women's business and satisfy the household daily income and food demand. But, during the discussion, the farmers indicated that diversification towards high egg-producing chicken breeds was unlikely to most of the poor farmers in the community. Because, one, these exotic breeds must be purchased from the potential breeders and, two, vaccinations are necessary for maintaining their health. Though these are expressions of strength and opportunity, they are demanding and unaffordable to many of the poor farmers. Thus, majority of the farmers opt to keep the old or traditional poultry breeds, though they are still less remunerative. This finding could answer the more important question. "What forms of diversification being chosen, and which are maladaptive in the study area?" And further, "Who is making the respective choices and why?" Asking these questions allows for an improved understanding of diversification: not all diversification is equal, not all people have equal opportunities to different forms of diversification, nor do all diversifications necessarily enhance adaptive capacity. The choices made by the farmers to get out of vulnerability, knowing that the strategies are still maladaptive, are the demonstrative of how it engages with diversification.

It is worth to note that the intensity of livestock diversification varies among the farm households, particularly between the asset rich and the poor. During the focus group discussions, it was disclosed that, for the poor, one sheep and goat may be owned or accessed through a share (yerbee)contract, whereby they look after livestock of better off households and in return are allowed to take the milk and a share of the progeny. The resource better-off farm households have more livestock than other households, owning at least two oxen and a considerable herd of cattle. Ownership of ox (a traction power which is means for production of household staple crops) is a very important livelihood asset among the rural agrarian. But the discussions convey that the resource poor farmers, unfortunately, have no ox and it means they fail to prepare their land timely.

\subsubsection{Crop Diversity}

Indeed, different forms of diversification in rural farm households' context of which crop-diversification is the sub-set of livelihood diversification (Idowu et al. 2014). Hence, it is interesting to know the nature of crop diversification in rural Kembata Tembaro zone where the tropical climate allows varieties of crops to be grown.

The crops planted by the smallholder farmers in the study area include chief cereals like maize, wheat, barley, teff, beans, and peas. Vegetables like potatoes, sweet potatoes, cassava, taro, onions, cabbage, carrot, red roots, and tomatoes are commonly produced by the small-scale farmers in the area. Commercial crops like coffee, ginger and khat, as well as fruits like banana, mango, avocado, oranges and papaya are produced both as consumption and cash crops. Most of the respondents (87\%) who participated on the door-to-door interview indicated that their own crop productions do satisfy for 80 to $85 \%$ of the household staples requirement. But, the rest $(13 \%)$ were unable to produce from their own farming to satisfy their household needs, and opt to relying heavily on working for others locally or elsewhere for cash income so that they can purchase food items from market or obtain as direct payment for labor, mainly in maize and processed enset - kotcho.

This finding can be a good manifestation characterizing the existing livelihood situation in the zone. The basic staple in the zone are maize, teff and wheat; while these are the main marketed crops, with the existing road access to main markets within the zonal cities and nearby market access. Those households with the capacity to utilize the opportunity are likely to produce the variety usually sell these crops and do earn better; while buying cheaper grains for the household food consumption. That means, for the better-off crop sales are the other highest income earning sources. This might pull the relatively the resource rich to stay on farming.

The group discussions pinpointed that the asset poor, to the contrary, do diversify to a lesser extent. The resource rich have the access and capacity to utilize farm inputs like improved seeds and fertilizers. The better off could hire and engage better labour (mainly, the poor household members) on land preparation, weeding, harvesting and threshing. Poor households rent out their land and sell their manual labor locally to better off households. Beyond producing very few crops, poor households are usually limited with resource and potential endowments and this makes them end meet by a variety of low-income economic activities, including casual labor, selling natural resources like firewood, and petty trade. Thus, these results go inconsonantly with the argument livelihood diversifications are not necessarily positive changes (Logan, 2018). Diversification in such a circumstance is not an expression of strength for the poor; rather it is a sign of vulnerability.

The results of the level of crop diversification of households are summarized on (Figure 2). The results showed that only $10(2.6 \%)$ of the respondents are mono croppers, whereas $24(6.25 \%)$ out of the total are the highest diversifying farmers. The rest of the farmers in the midline of the continuum and they are known for diversifying their cropping. 


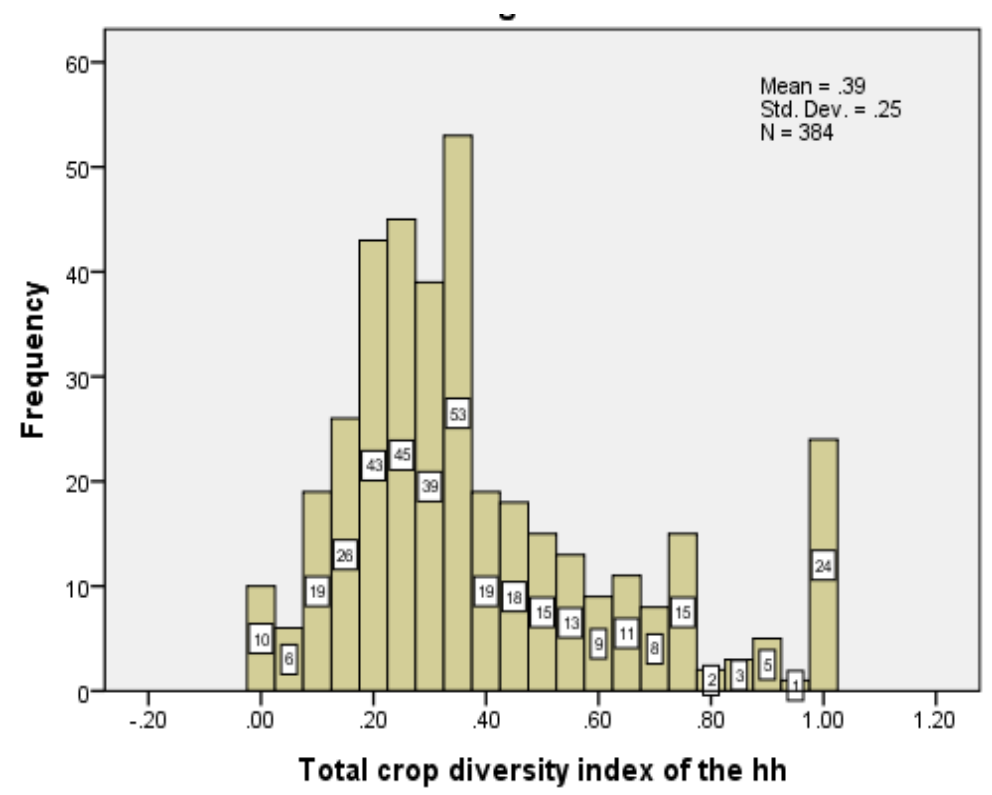

Figure 2. Crop diversity distribution

Source: Survey data (2016)

It should be noted that crop diversification, in the context of this study, means cultivating more number of crops at a crop season. As they reflected during the focus group discussions, most of the farmers in the study area did not depend on one type of crop because of different risks associated with crop production including market price fluctuation, drought, excessive rain fall, climate change, crop diseases, and calamities like fire. This diversification strategy is adopted to ensure secured livelihood among smallholder farmers. The assumption is that crop diversity, specifically the number of crops utilized in the production system, particularly in rain-fed agricultural areas with variable rainfall, would strengthen food security. The logic supporting this conclusion is that having multiple options reduces risk because if one crop fails or has a less than ideal yield, the other crops may produce as expected and thus mitigate the risks. The findings are consistent with Almaz and Anke (2004) arguing that with such a diversified production, livelihoods have been food secure in this zone. Nevertheless, shortage of land is becoming a more acute problem for the poorer half of the growing population, and this threatens to limit their self-sufficiency in the future.

\subsubsection{Diversification of Income Sources}

Based on our assumptions established (see 2.3.1.), six major income sources were identified and household annual income was accounted from the survey data. These include livestock rearing, food crop productions, commercial crop productions, wage employments, rural enterprises, and remittance. Table 4 gives the descriptive statistics of our sample households. Regarding the structure of occupations, households are basically concentrated more on agriculture including both livestock rearing (88.8\%) and crop production (95.5\%) and there is also significant size $(75.5 \%)$ of farm households engaged in production of commercial crops such as coffee, ginger and khat. This can be an indicator for attraction of market-oriented farm production, though land is highly fragmented.

Table 4. Frequency distribution and diagnostic statistics of annual households' income (in Birr) generated from principal economic activities

\begin{tabular}{lllllll}
\hline Income sources & $\boldsymbol{f}$ & \% & Min. & Max. & Mean & St. Dev. \\
\hline Livestock rearing & 342 & 88.8 & 20.00 & 164120.00 & 8086.56 & 13644.68 \\
Subsistence crop production & 369 & 95.5 & 150.00 & 24500.00 & 5354.23 & 4353.44 \\
Commercial crop production & 299 & 75.5 & 450.00 & 200000.00 & 8592.03 & 19170.91 \\
Wage employments & 110 & 29.8 & 200.00 & 60000.00 & 3275.24 & 8829.47 \\
Rural enterprises & 285 & 78.1 & 200.00 & 254000.00 & 5032.09 & 15207.64 \\
Occupational migration & 86 & 24.2 & 50.00 & $60,000.00$ & 2277.11 & 8048.88 \\
\hline
\end{tabular}

Source: Survey data (2016) 
The results indicated superiority order of livelihood strategies in terms of the average annual cash income obtained by the households. Accordingly, commercial crop production stands as the first lucrative livelihood strategy in terms of the average cash income obtained by the agrarian households. Next to commercial crops, livestock rearing with the average cash income per annum of 8086.56 birr/household was found to be the second reliable livelihood strategy. Subsistence crop production is the third attractive livelihood strategy. From these findings it can be concluded that there is heavy reliance on within agricultural diversification as the most remunerative livelihood strategy for small-scale peasantry livelihood situations. Although other off/non-farm choices are available, they offer less income to small-scale farm households. As a result, the more farm households are capable of maintaining crop production and livestock herding, the better their annual cash income is.

\subsection{Clustering Households on the Basis of Livelihood Strategy Groups}

The results from the hierarchical cluster analysis are given in the dendogram (Figure 3) below. It indicates the number of cluster solutions available as one move from the top to the bottom. The cluster solution is given by dissecting the dendogram at a linkage distance of 90 , at which 5 cluster livelihood strategy groups emerge from the exercise. This step in the analysis points to relative homogenous clusters to be formed in the next step, non-hierarchical clustering which ultimately gives the same number of cluster solutions.

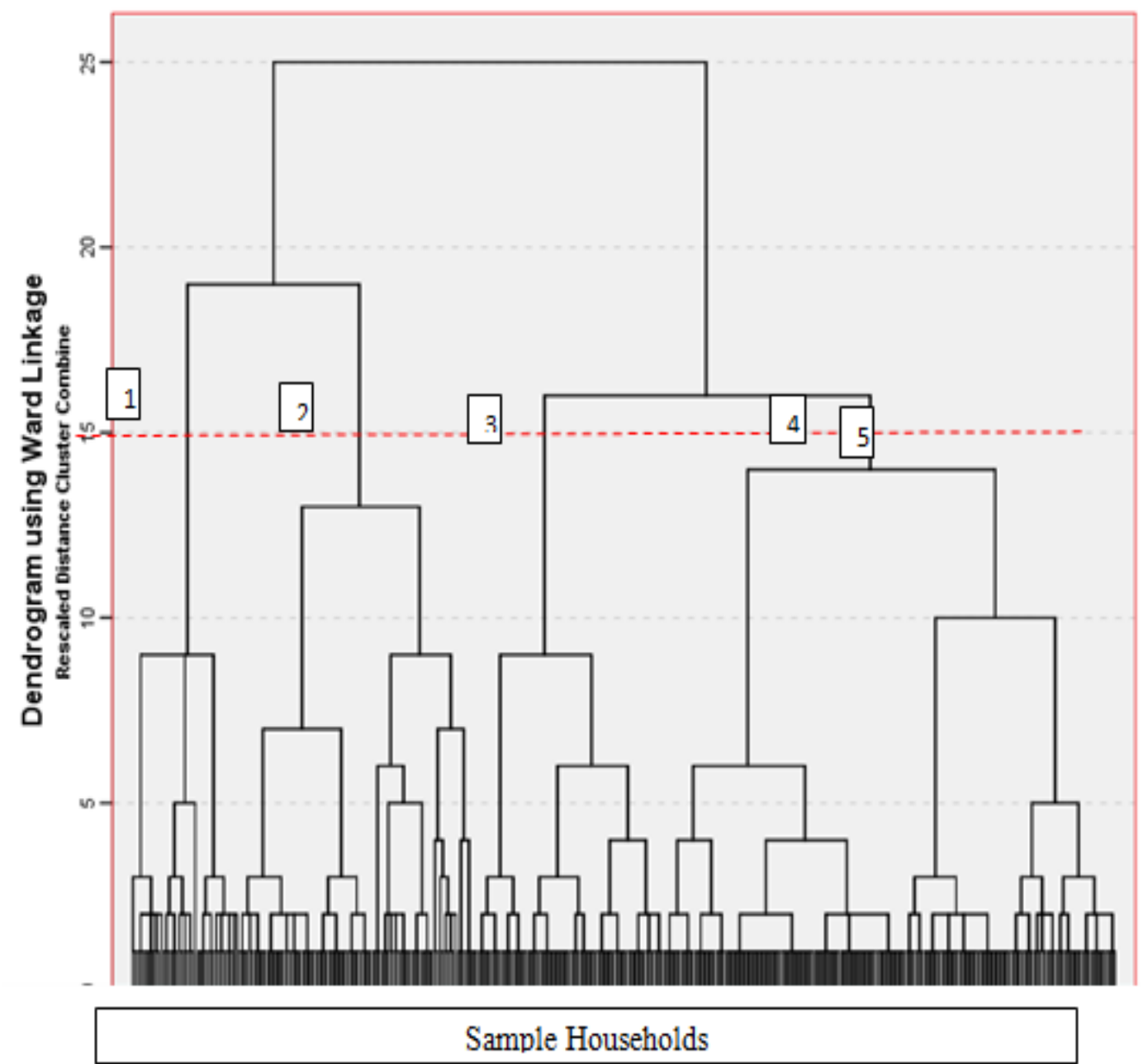

Figure 3. Dendrogram Using Ward Linkage (Clusters of households on Livelihood Strategies' Basis)

The non-hierarchical $K$-means clustering procedure yielded the results given in Table 5. It indicates the mean values within clusters in order to understand differentiation amongst the farming household groups. Each cluster is defined by its main characteristics and therefore explains the homogeneous livelihood strategy groups of households in the study area. 
Table 5. Descriptive statistics of the $K$-means cluster analysis for livelihood strategies

\begin{tabular}{|c|c|c|c|c|c|c|c|c|c|c|c|}
\hline \multirow[t]{2}{*}{ Cluster } & \multirow{2}{*}{$\begin{array}{l}\text { Number } \\
\text { of } \\
\text { cases (n) }\end{array}$} & \multirow{2}{*}{$\begin{array}{l}\text { Monthly } \\
\text { income (in } \\
\text { birr) }\end{array}$} & \multicolumn{6}{|c|}{ Shares of IGAs (in \%) } & \multirow[t]{2}{*}{ IGAs } & \multirow[t]{2}{*}{ TLU } & \multirow[t]{2}{*}{ Land } \\
\hline & & & $\begin{array}{l}\text { Subss } \\
\text { crops }\end{array}$ & $\begin{array}{l}\text { Comm. } \\
\text { crops }\end{array}$ & Livestock & SMEs & Wage & Remit. & & & \\
\hline 1 & 98 & 1749.13 & 57.55 & 0.11 & 31.55 & 4.87 & 3.20 & 2.71 & 3 & 2.38 & 0.34 \\
\hline 2 & 41 & 7356.72 & 1.29 & 60.36 & 26.4 & 0.81 & 7.92 & 3.2 & 5 & 3.87 & 1.5 \\
\hline 3 & 71 & 2861.52 & 0.25 & 0.65 & 28.19 & 1.66 & 69.25 & .00 & 3 & 3.56 & 0.36 \\
\hline 4 & 81 & 2478.42 & 7.77 & 1.33 & 9.20 & 65.64 & 13.14 & 2.89 & 5 & 2.4 & .43 \\
\hline 5 & 93 & 5826.02 & 5.1 & 2.81 & 0.25 & 15.78 & 0.00 & 76.30 & 3 & 2.2 & .25 \\
\hline
\end{tabular}

Keys: IGA= Income Generating Activities; SME= Small and Micro Enterprises; TLU= Tropical Livestock Unit

- Cluster 1: Non-commercial smallholder farmers (Subsistence Farmers)

- Cluster 2: Emerging commercial farmers

- Cluster 3: Wage employees

- Cluster 4: Rural entrepreneurs

- Cluster 5: Occupational migrants

The first cluster (98 households) from the analysis is typically small-scale peasantry families living on subsistence farming. These households are characterized by generating their consumption needs mainly from subsistence crops $(57.55 \%)$ such as enset, cereals, pulses, root crops, vegetables, and fruits. Though these are of low income return crops, most of them are drought resistant and staple food for the rural farmers in the study area. The second considerable size of average income (31.55\%) for these household groups comes from sales of livestock and livestock products. The livelihood of these category groups, therefore, is laid on subsistence mixed-farming system. The average income for these households is 1749.13 Birr per month. The smallest proportion $(0.11 \%)$ of household income for these households comes from sales of commercial crops. As indicated in Table 5 these households are characterized by owning the second lowest, next to the fifth cluster groups, average farm land size ( $0.34 \mathrm{ha}$ ) of all the categories.

The second group of households- emerging commercial farmers- are representing the smallest amount of the households surveyed (41 out of 384). But they are the richest group in terms of average monthly income earning (7356.72 Birr). The income is mostly generated from sales of commercial crops $(60.36 \%)$ which include coffee, ginger, and Khat. Livestock rearing is the second big livelihood strategy in the study area. The survey results show that $26.4 \%$ households involve in livestock rearing. Farm land size is relatively largest for these groups (1.5 ha in average). This could be a reflection for their better potential which may trigger their tendency to market-oriented production.

The third group of households - 'wage earners' - account for about 71 out of the total sample of rural households. They are the second from the least majority here. They derive their largest gross income $(69.25 \%)$ from off-farm employment and casual labour. Formal employments, religious and cast related jobs, and working in others' farms for daily wage are the major livelihood activities for these categories. The vast majority of working household members must commute to work, or have to leave home and stay the solid day in nearby urban areas or others' farm yards for casual labor or formal employments.

Non-farm self-employment or rural informal enterprises are the other livelihood specialty chosen as lucrative activity by 81 households out of the total observations. These small businesses are including petty trade like local shops, involving rural transportation, restaurants, and sales of local beverages. These household businesses are mainly run either in their own homes or local market premises. Sales of natural products such as charcoal, firewood, eucalyptus tree, domestic animal feeds, and sales of raw materials for construction in the nearby urban areas are the other major rural entrepreneurial businesses. Masonry, carpentry, metal work, weaving, knitting, embroidery, tailoring, henna, pottery, jewelery, tanning, hairdressing, and traditional healing are also common rural small-enterprises in the study area.

The other livelihood strategy group- occupational migrants- are represented by the next largest number of households, next to non-commercial smallholder farmers; that is 93 out of the total sample households (Table 5). The households following this livelihood strategy show average monthly income of 5826.02 Birr, which is the second biggest gross income next to the emerging-commercial farm households' cluster. The households are mainly dependent on remittances or transfers (with $76.30 \%$ of household total income share) coming from at least a member of the household who is migrated to any of the three patterns: out-nationally, intra-regionally 
(permanent movement within one region of a country) or inter-regionally (movement out of a region in a country). Households in this livelihood strategy are with the least average farm land tenure ( $0.25 \mathrm{ha})$.

The key informants disclosed that occupational migration is typified as a preferred livelihood option by majority. Particularly, both cross-border migration mainly to destinations like Republic of South Africa and the Gulf States, and internal rural-urban migration are taken as the get way out for the rural mass of the study area. Despite this fact, the respondents underlined that migration is an expression of vulnerability or duress. They put their argument with justification that majority of rural youth would migrate in response to extreme difficulties such as unemployment, food shortage, and poverty within their household. Youth migrants seeking unskilled, uncertain, temporary low-paid, unskilled and precarious labor work often relocate to nearby towns and cities, with young men hoping to work on construction sites and young women in the service sector. Migration of this form is a compounding of vulnerabilities: whether an immediate food shortage in the household or the long-term inability to support children to complete their education. As the key informants emphasized, generalizations about migrations as livelihood choices neglect the complexity of lived reality - not all migrations are ending up positive. While some migration choices are proactive choices based on long-term planning and investment for permanent and relatively well-paid work, others are indicative of serious challenges being encountered, with choices being made to address immediate needs, often with long-term negative consequences.

\section{Conclusion}

In summing up, the results of examining livelihood diversification patterns of farm households indicated that the patterns of smallholder farmers' diversification took different forms. In the literature, there are two controversial positions about livelihood diversification. Much of the research, policies, and programs in an optimist side about it view and recommend diversification as best alternative for sustainable rural livelihoods (Gecho, Ayele, Lemma \& Alemu, 2014; Headey, Tafesse \& You, 2014; Megersa et al., 2014; Shiferaw et al., 2014; Tsegaye et al., 2013; Oskam \& Woldenhanna, 2001; Yosef et al., 2013). The other dichotomies are those suggesting theoretical possibilities which are skeptic towards diversification. They suggest reducing diversification and focusing on monoculture cropping and/or husbandry, particularly moving towards high value commercial production systems as a best means of reducing rural poverty and vulnerability (Tefera, 2009). However, recommending neither of a theoretical possibility (diversification or the monoculture) is the interest of the present study. Rather, it emphasized on analyzing on what farmers are practicing; the choices that they are actually making. Within the studied communities, diversifications are occurring, and what we put forward is an assessment of those diversifications in light of their lucrativeness for the rural livelihoods. There are the clear limitation of formulating generalizable diversification strategies over time, because each strategy is highly region-explicit and depend on frame conditions (which differ always).

Based on the results of the present investigation, it could be wrapped up that diversification by itself is neither positive nor maladaptive. It can only be a viable strategy to achieve sustainable rural livelihoods if the farmers are capacitated so that they can choose the right remunerative livelihood strategy among the existing options.

\section{References}

Abo, T., Rajan, S., \& Geta, E. (2018). Nexus between Household Asset Base and Agrarian Livelihood Strategies' Diversification: Using Multidimensional Approach. Asian Journal of Agricultural Extension, Economics \& Sociology, 22(4), 1-17. https://doi.org/10.9734/AJAEES/2018/39355

Adesiji, G. B., Akinsorotan, A. O., \& Omokore, D. F. (2010). Farmers' assessment of extension services on Ogun State, Nigeria. Journal of Agricultural and Food Information, 11(2), 143-156. https://doi.org/10.1080/10496501003691661

Alemu, Z. G., Oosthuizen, L. K., \& Van Schalkwyk, H. D. (2010). Agricultural development policies of Ethiopia since 1957. University of the Free State.

Alinovi, L., Mane, E., \& Romano, D. (2009). Measuring household resilience to food insecurity: Application to Palestinian households. Working paper. Food and Agriculture Organization of the United Nations (FAO). Rome. https://doi.org/10.1002/9780470665480.ch21

Alinovi, L., D'Errico, M., Mane, E., \& Romano, D. (2010). Livelihoods Strategies and Household Resilience to Food Insecurity: An Empirical Analysis to Kenya. Food and Agriculture Organization of the United Nations (FAO): Rome, Italy.

Almaz, N., \& Anke, N. (2004). The significance of enset culture and biodiversity for rural household food and livelihood security in southwestern Ethiopia. Agriculture and Human Values, 2(1), 61-71. https://doi.org/10.1023/B:AHUM.0000014023.30611.ad 
Amare, D., \&Belaineh, L. (2013). Determinants of income diversification among rural households: The case of smallholder farmers in Fedis district, Eastern Hararghe zone, Ethiopia. Journal of Development and Agricultural Economics, 5(3), 120-128. https://doi.org/10.5897/JDAE12.104

Ashley, C., \& Carney, D. (1999). Sustainable Livelihoods: Lessons from early experience. Department for International Development: London.

Ballas, D., Kalogeresis, T., \& Labriandis, L. (2003). A comparative study of typologies for rural development

Ballas, D., Kalogeresis, T., \& Labriandis, L. (2003). A comparative study of typologies for rural areas in Europe. Paper at the 43rd European Congress of the Regional Science Association: Centre for Computational Geography.

Barrett, C., Bezuneh, M., \&Abdillahi, A. (2001). Income diversification, poverty traps and policy shocks in Cote d'Ivoire and Kenya. Food Policy, 26(4), 367-384. https://doi.org/10.1016/S0306-9192(01)00017-3

Bernard, T., Eleni, G., \& Alemayehu, S. T. (2007). Smallholder's Commercialization through Cooperatives: A Diagnostic for Ethiopia. IFPRI Discussion Paper No. 00722, Oct.

Bidogeza, J., Berentsen, P., De Graaf, J., \& Oude, L. A. (2009). A typology of farm households for the Umutara Province in Rwanda. Food Security, 1, 321-35. https://doi.org/10.1007/s12571-009-0029-8

Block, S., \& Webb, P. (2001). The Dynamics of Livelihood Diversification in Post-Famine Ethiopia. Food Policy, 26, 333-350. https://doi.org/10.1016/S0306-9192(01)00015-X

Cavendish, W. (2002). Quantitative methods for estimating the economic value of resource use to rural households. SAGE: Los Angeles.

Chambers, R., \& Conway, G. (1992). Sustainable rural livelihoods: Practical concepts for the 21st century. Institute of Development Studies: London.

Cochran, W. G. (1963). Sampling techniques. (2nd Ed.), New York: John Wiley and Sons, Inc.;

Cochran, W. G. (1963). Sampling Techniques. Wiley: New York.

CSA (Central Statistics Agency). Ministry of Finance and Economic Development. Agricultural Sample Survey Study Documentation. CSA: Addis Ababa; 2012.

De Graaf, J. (2011). Measuring the effectiveness of research and development on avocado, Perseaamericana Mill, in South Africa. Research Report. Graduate School of Business Leadership.

Degefa, T. (2005). Rural Livelihoods, Poverty and Food Insecurity in Ethiopia: A case study at Erenssa and Garbi communities in Oromiya zone, Amhara National Regional State. Norwegian University of Science and Technology (NTNU): Trondheim.

Ellis, F., \& Allison, E. (2004). Livelihood diversification and natural resource access: Overseas Development Group. Working paper 9. University of East Anglia: Norwich.

Ellis F. (2000). Rural Livelihoods and Diversity in Developing Countries. Oxford University Press: Oxford.

Ellis F. (2000a). Rural livelihoods and Diversity in Developing Countries. Oxford University Press: Oxford.

Ellis, F., \& Freeman, H. (Eds.) (2005). Rural Livelihoods and Poverty Reduction Policies, Engineering, 87(4), 509-521.

Everitt, B., Landau, S., Leese, M., \& Stahl, D. (2001). Cluster analysis. 5th ed. Wiley: London.

Eyasu, E. (2002). Farmers perceptions of change and management of soil fertility. SOS Sahel-Sahel and Institute of Development studies. Addis Ababa, pp. 252.

Fisher, M., (2004). Household welfare and forest dependence in Southern Malawi. Environment and Development Economics, 9(2), 135-154. https://doi.org/10.1017/S1355770X03001219

Food and Agriculture Organization (FAO). Special Report: Crop and Food Supply Assessment Mission to Ethiopia. WFD, Rome; 2011.

Gaspar, P., Escribano, M., Mesias, F. J., Rodriguez de Ledesmab, A., \& Pulido, F. (2008). Sheep farms in the Spanish rangelands (dehesas): Typologies according to livestock management and economic indicators. Small Ruminant Research, 74, 52-63. https://doi.org/10.1016/j.smallrumres.2007.03.013

Gebreselassie, A., \& Bekele, T. (2010). A review of Ethiopian agriculture: roles, policy and small-scale farming systems. Ethiopia and D. R. Congo. 
Gecho, Y., Ayele, G., Lemma, T., \& Alemu, D. (2014). Rural household livelihood strategies: Options and determinants in the case of Wolaita zone, Southern Ethiopia. Social Sciences, 3(3), 92-104. https://doi.org/10.11648/j.ss.20140303.15

Geremew, W. (2017), The Nexus between livelihood diversification and farmland management strategies in rural Ethiopia. Cogent Economics \& Finance, 5, 1275087 http://dx.doi.org/10.1080/23322039.2016.1275087

Girma, A. (2013). The challenges and policies of poverty reduction in Ethiopia. The Challenges and Policies of Poverty Reduction in Ethiopia. Addis Ababa.

Greene, W. (2012). Econometric analysis. (7th ed.). Prentice Hall, New Jersey

Headey, D., Taffesse, A. S., \& You, L. (2014). Diversification and development in pastoralist Ethiopia. World Development, 56, 200-213. https://doi.org/10.1016/j.worlddev.2013.10.015

Laura, D., Bruna, G., Alicia, M., David, G., Deborah, J., Obinna, O., Rita, P., Elizabeth, A., Debbie, L., \& James, R. (2012). Measuring socio-economic position for epidemiological studies in low- and middle-income countries: a method of measurement in epidemiology paper. International Journal of Epidemiology, 41(3), 871-886. https://doi.org/10.1093/ije/dys037

Liao, C., Sullivan, P., Barrett, C., \& Kassam, K. (2014b). Socio-environmental Threats to Pastoral Livelihoods: Risk Perceptions in the Altay and Tianshan Mountains of Xinjiang, China. Risk Analysis, 34(4), 640-655. https://doi.org/10.1111/risa.12146

Maseda, F., Diaz, F., \& Alvarez, C. (2004). Family dairy farms in galicia (N.W. Spain): Classification by some family and farm factors relevant to quality of life. Biosystems. https://doi.org/10.1016/j.biosystemseng.2004.01.002

Megersa, B., Markemann, A., Angassa, A., Ogutu, J., Piepho, H., \& Zarate, A. (2014). Livestock diversification: An adaptive strategy to climate and rangeland ecosystem changes in southern Ethiopia. Human Ecology, 42, 509-520. https://doi.org/10.1007/s10745-014-9668-2

Mulugeta, H. (2014). 'Green Famine' in Ethiopia: Understanding the causes of increasing vulnerability to food insecurity and policy responses in the Southern Ethiopian Highlands. A PhD dissertation submitted to University of Sussex. pp. 280.

Naraian, U., Gupta, S., \& Veld, K. V. (2005). Poverty and environment: Exploring the relationship between household incomes, private assets, and natural assets. Resource for the Future. Discussion paper: 05-18. https://doi.org/10.2139/ssrn.850071

Reardon, T., Taylor, J. E., Stamoulis, K., Lanjouw, P., \& Balisacan, A. (2000). Effects of Non-farm Employment on Rural Income Inequality in Developing Countries: An Investment Perspective. Journal of Agricultural Economics, 51(2), 266-288. https://doi.org/10.1111/j.1477-9552.2000.tb01228.x

Reta, H., \& Ali, H. (2012). Livelihood diversification among the agricultural land scarce peasants in the centeral highlands of Ethiopia. International Journal of Agricultural Science, Research and Technology, 2(1), 1-8.

Rui, S., Jianing, M., Shu, C., \& Xiao, G. (2019). Classifying Livelihood Strategies Adopting the Activity Choice Approach in Rural China: MDPI. Sustainability, 11, 3019. https://doi.org/10.3390/su11113019

Scoones, I. (1998). Sustainable livelihoods, a framework for analysis. IDS working paper. No. 72, Brighton.

Shiferaw, B., Tesfaye, K., Kassie, M., Abate, T., Prasanna, B., \& Menkir, A. (2014). Managing vulnerability to drought and enhancing livelihood resilience in sub-Saharan Africa: Technological, institutional and policy options. Weather and Climate Extremes, 3, 67-79. https://doi.org/10.1016/j.wace.2014.04.004

SNNPR (Southern Nations, Nationalities and People's Region). (2008). The Socio-Economic Profile of the Southern Nations, Nationalities, and Peoples' Region, Ethiopia: Hawassa.

Taylor, F., \& Adelman, D. (2003). Development from Within: Survival in Rural Africa. Routledge: New York.

Tefera, T. (2009). Supply response, local reality and livelihood sustainability: The policy dilemma of khat (Catha edulis) production in eastern Ethiopia. International Journal of Agricultural Sustainability, 7(3), 176-188. https://doi.org/10.3763/ijas.2009.0428

Tsegaye, D., Vedeld, P., \& Moe, S. (2013). Pastoralists and livelihoods: A case study from northern Afar, Ethiopia. Journal of Arid Environments, 91, 138-146. https://doi.org/10.1016/j.jaridenv.2013.01.002

Twine, W., Moshe, D., Nethslluvhi, T., \& Slphugu, V., (2003). Consumption and direct use value of savannah bio-resources used by rural households in Mametja, a semi-arid area of Limpopo province, South Africa. 
South African Journal of Science, 99, 467-473.

Winters, P. Davis, B. \& Carrol, L. (2002). Asset, activities and income generation in rural Mexico: Factoring in social and public capital. Agricultural Economics, 27(2), 139-56.

https://doi.org/10.1111/j.1574-0862.2002.tb00112.x

Woldenhanna, T., \& Oskam, A. (2001). Income diversification and entry barriers: evidence from the Tigary region of Northern Ethiopia. Food Policy, 26, 351-365. https://doi.org/10.1016/S0306-9192(01)00009-4

Yosef, T., Mengistu, U., Mohammed, Y. K., \& Kefelegn, K. (2013). Camel and cattle population dynamics and livelihood diversification as a response to climate change in pastoral areas of Ethiopia. Livestock Research for Rural Development, 25(9), 1-10.

Zerai, B., \& Gebreegziabher, Z. (2011). Effect of non-farm income on household food security in eastern Tigray, Ethiopia: an entitlement approach. Food Science and Quality Management, 1(10), 1-23.

\section{End Note 1}

The World Bank's Rural Strategy "smallholders" as those with a low asset base, operating less than 2 hectares of cropland (World Bank 2003) and FAO study defines smallholders as farmers with "limited resource endowments, relative to other farmers in the sector" (Dixon et al., 2003)

\section{End Note 2}

${ }^{\mathrm{i}}$ Following (Chattopadhyay, 2010; Ibrahim et al. 2009), Simpson Index was used to determine the pattern of crop diversification among farm households.

$$
I=1-\sum_{i=1}^{n} A_{i}^{2}
$$

Where:

$$
A_{i}=\frac{X_{i}}{\sum X_{i}}
$$

Where:

$X_{i}=$ planted area of $i^{\text {th }}$ crop, $\mathrm{i}=1,2,3, \ldots . \mathrm{n}$

$A_{i=}$ proportion of planted area of the $i^{\text {th }}$ crop in the total cultivated land of the household; When $I$ show a value of zero, it means that the farmer is least diversifying while the value of 1 indicates the most diversified.

\section{Copyrights}

Copyright for this article is retained by the author(s), with first publication rights granted to the journal.

This is an open-access article distributed under the terms and conditions of the Creative Commons Attribution license (http://creativecommons.org/licenses/by/3.0/). 